\title{
Upaya Organisasi Nirlaba (NGO) Bertahan di Masa Pandemi Covid 19
}

\section{Efforts of Non-Profit Organizations (NGOs) to Survive in the Covid-19 Pandemic Period}

\author{
Muhammad Nur Abdillah
}

Universitas Dian Nuswantoro Semarang

Jl. Imam Bonjol No. 207, Semarang, Indonesia

Email: abidnoora@icloud.com

Received : June 4, 2021 ; Revised: July 22, 2021; Accepted: August 20, 2021

\begin{abstract}
The pandemic has an impact on many sectors, causing changes in the pattern of activities carried out in general. The pandemic has also affected non-profit organizations (NGOs), Dejavato is no exception. More than 15 years of existence, the organization located in Semarang has 59 university partners, 34 SMP / MTs partners, 60 SMA / SMK partners, 13 TK / PAUD partners, 21 SD / MI partners, and 20 other foundation partners spread across almost all of the region in Indonesia. This shows that Dejavato has credibility and a strong influence on the local community. The existence of a pandemic makes the Dejavato Foundation to adapt to use online media to survive, because of the cessation of offline activities that result in the achievement of vision threatened to fail. This article aims is to determine the efforts to utilize digital media during the pandemic by the Dejavato Foundation. This research uses a qualitative method with a case study approach where after the data was collected, pattern matching was carried out to validate the data found. The theory that is used in this research is the theory of e-PR and Stakeholder Theory. The primary data was collected through interviews with the founder and public relations coordinator of the Dejavato Foundation, and observation. Meanwhile, to collect the secondary data, the researcher was using the documentation technique. The result of this study shows that Dejavato, in terms of optimizing digital media is by using several methods; convergence of programs, use of e-PR tools, especially social media, dejavatalk, and help empower people online. That shows how much the negative cause in this pandemic, especially for voluntary world.
\end{abstract}

Keywords: Covid-19; Digital Media; Non-Profit Organization; Pandemic; Stakeholder Theory; Volunteering.

Abstrak
Pandemi Covid-19 memberi dampak pada berbagai sektor tak terkecuali pada NGO
(organisasi nirlaba) Dejavato yang memiliki kegiatan utama pengiriman volunteer di
berbagai negara. Dejavato merupakan NGO yang telah berdiri lebih dari 15 tahun di Kota
Semarang dengan jumlah mitra hingga 207 yang berasal dari mitra TK, SD, hingga
perguruan tinggi di Indonesia. Hal tersebut menunjukkan bahwa Dejavato memiliki
kredibilitas serta pengaruh yang kuat bagi masyarakat lokal. Adanya pandemi membuat
Dejavato Foundation untuk beradaptasi menggunakan media daring untuk bertahan, 
sebab terhentinya aktivitas luring yang mengakibatkan pencapaian visi terancam gagal. Artikel ini bertujuan untuk mendeskripsikan inovasi yang dilakukan oleh Dejavato Foundation terkait penggunaan media baru dalam menghadapi masa pandemi. Teori yang digunakan dalam penelitian ini adalah teori $e-P R$ serta Stakeholder Theory. Artikel ini merupakan jenis penelitian kualitatif dengan metode studi kasus. Proses pengolahan data dilakukan dengan pengumpulan data, penjodohan pola dan analisis data sesuai dengan teori. Subjek penelitian ini adalah pendiri dan koordinator humas Dejavato Foundation. Hasil penelitian menunjukan bahwa Dejavato melakukan berbagai upaya dalam menghadapi pandemi, yaitu: konvergensi program, pemanfaatan media sosial, mengadakan event dejavatalk, serta membantu memberdayakan masyarakat secara daring. Hal tersebut berarti bahwa pandemi berdampak luas, dan masif bagi dunia sukarelawan.

Kata Kunci: Covid-19; New Media; Organisasi Nirlaba; Pandemi; Stakeholder Theory; Volunteering.

\section{Pendahuluan}

Akibat maraknya bahaya pandemi, serta diblokirnya akses masuk warga asing sampai saat ini menyebabkan LSM yang fokus pada pertukaran sukarelawan mengalami penurunan atau bahkan pemberhentian dalam pertukaran sukarelawan. Diblokirnya Indonesia sebagai tujuan bepergian, berakibat terhentinya kegiatan NGO terhenti, maka ditemukan tidak ada volunteer yang masuk. Dapat disimpulkan bahwa Dejavato mengalami hambatan dalam pelaksanaan misi yang ditetapkan di awal dalam mencapai visi organisasi selama pandemi berlangsung hingga saat ini.

Siklus perputaran yang terganggu dalam organisasi membuat hubungan internal dengan pemangku kepentingan eksternal menjadi terganggu juga. Visi serta misi Dejavato yang berfokus pada memperkenalkan budaya sukarelawan kepada masyarakat tidak dapat berlangsung dengan normal, bahkan sempat terhenti semasa pandemi. Adanya kejadian tidak terduga seperti ini, Dejavato dituntut untuk beradaptasi dengan cara lain yang tidak membahayakan kesehatan juga agar tetap dapat menjalin komunikasi dengan publik serta mempertahankan keberlangsungan organisasi.

Pandemi yang dirasakan pertama kali oleh Dejavato adalah hal yang tidak terduga, bahkan Ketut Purwanto menjelaskan "Sejujurnya kami belum siap dengan adanya pandemi ini”. Tetapi dengan adanya masalah yang dirasakan Dejavato ini justru menjadikan Dejavato sebagai salah satu NGO dengan aktivitas daring yang berhasil membawa organisasi bertahan dengan memanfaatkan sumber daya digital. 2 Maret 2020, pemerintah resmi megumumkan kasus corona virus diumumkan ke hadapan publik (Pranita, 2020). Masuknya corona virus ke Indonesia berdampak pada menurunnya jumlah kunjungan orang asing ke dalam negara Indonesia. Terdapat 59 negara yang melarang warganya datang ke Indonesia di masa pandemi. Warga dari Indonesia pun tidak diperkenankan berkunjung ke daftar negara di atas. Munculnya kebijakan larangan kunjungan ke Indonesia maupun sebaliknya 
merupakan langkah preventif pemerintah untuk menekan penyebaran Covid 19 di Indonesia.

Dejavato merupakan salah satu dari organisasi nirlaba yang berada di Kota Semarang dan bergerak di bidang voluntary service sejak tahun 2005. Keluar-masuknya sukarelawan dari luar negeri maupun dalam negeri yang mengikuti program luar negeri merupakan nilai utama dari Dejavato. Organisasi ini mempunyai kredibilitas serta pengaruh yang kuat di masyarakat. Terdapat 59 Mitra perguruan tinggi yang telah atau sedang menjalin kerja sama dengan Dejavato, baik Internasional maupun interlokal. Selain itu terdapat 13 mitra TK/PAUD, 21 mitra SD/MI, 34 mitra SMP/MTs, 60 mitra SMA/SMK, serta 20 mitra yayasan yang tersebar di hampir seluruh penjuru daerah di Indonesia (Foundation, 2019).

Dejavato dapat menjalankan misi di berbagai daerah melalui misi yang dijalankannya. Berdasarkan hasil observasi yang dilakukan, pendiri Dejavato menyatakan bahwa Organisasi ini sifatnya Independen dan merupakan organisasi lokal yang dirintis sejak awal tanpa bantuan organisasi induk.

Pada awal kemunculan

Pandemi di Indonesia, muncul kebijakan terkait diblokirnya akses masuk warga asing yang menyebabkan Dejavato mengalami pemberhentian dalam pertukaran sukarelawan. Dari hasil observasi yang dilakukan, bulan Januari-Maret dan Juli-September selalu menjadi bulan dilaksanakannya pertukaran sukarelawan (hingga kurang lebih 40-50 orang) untuk berbagai tujuan sesuai kerjasama yang dilakukan dengan mitra. Namun di masa pandemi, kegiatan $N G O$ otomatis terhenti dikarenakan tidak ada volunteer yang masuk. Hal ini tentu saja menjadi hambatan dalam pelaksanaan misi yang ditetapkan di awal dalam pencapaian visi organisasi selama pandemi berlangsung hingga saat ini. Visi serta misi Dejavato yang berfokus pada memperkenalkan budaya sukarelawan kepada masyarakat tidak dapat berlangsung secara normal.

Siklus perputaran yang terganggu dalam organisasi membuat hubungan internal dengan pemangku kepentingan eksternal menjadi terganggu juga. Visi serta misi Dejavato yang berfokus pada memperkenalkan budaya sukarelawan kepada masyarakat tidak dapat berlangsung dengan normal, bahkan sempat terhenti semasa pandemi. Adanya kejadian tidak terduga seperti ini, Dejavato dituntut untuk beradaptasi dengan cara lain yang tidak membahayakan kesehatan juga agar tetap dapat menjalin komunikasi dengan publik serta mempertahankan keberlangsungan organisasi.

Tidak seperti organisasi lain yang berfokus pada sektor volunteering, atau hanya menyalurkan bantuan saja, Dejavato dalam pelaksanaan pemanfaatan media digital ini juga melakukan pemberdayaan yang diintegrasikan dalam media daring seperti The Dije dan Tim Satgas. Hal tersebut yang menjadikan Dejavato sebagai organisasi yang berbeda baik dari sudut pandang organisasi sosial, maupun sukarelawan yang ada di Indonesia atau internasional. Ketika 
organisasi lain hanya mencoba menerima lalu menyalurkan, Dejavato yang tergabung dalam dinas sosial mencoba memberdayakan, di samping hanya menyalurkan.

Pada akhirnya, Dejavato dituntut untuk beradaptasi dengan pandemi melalui beragam inovasi yang dilakukan dengan mengoptimalkan media baru sebagai bagian dari menjalin komunikasi dengan publik serta mempertahankan keberlangsungan organisasi.Aktivitas daring dapat menjadi satu-satunya jalan untuk tetap melaksanakan kegiatan.

Salah satu alat teknologi komunikasi yang digunakan sebagai promosi dan komunikasi adalah sosial media. Sosial media menjadi fasilitas mengakses informasi tanpa mengenal batas, ruang, jarak dan waktu (Pratiwi, dkk, 2019). Selain itu, aktivitas daring dinilai efektif sebagai substituen dikarenakan pada tahun 2018, pengguna internet Indonesia mencapai 171.176.716,8. Angka tersebut adalah hasil dari pertumbuhan 27.916.716 pengguna baru dari tahun sebelumnya (Asosiasi Penyelenggara Jasa Internet Indonesia, 2020). Evolusi dalam komunikasi perlahan berlangsung, masyarakat telah berangkat dari kanal komunikasi tradisional menuju teknologi. Penelitian ini bertujuan untuk mendeskripsikan berbagai inovasi terkait penggunaan media baru yang dilakukan oleh Dejavato Foundation di pandemi. Pada Pada artikel ini akan dibahas bagaimana Dejavato memanfaatkan media digital sebagai platform bertahan mereka beserta interpretasi mengenai apa pesan atau maksud yang ingin dibentuk secara perlahan oleh Dejavato di masa pandemi ini.

\section{Kerangka Teori \\ 2.1. e-PR Theory}

Hubungan masyarakat online (Heath, 2013) mencakup tools hubungan masyarakat tradisional (media publik, media yang dikendalikan, acara, dan komunikasi antarpribadi) dengan menggunakan Internet dan teknologi nirkabel seluler untuk mengelola komunikasi. Tujuannya adalah untuk menjembatani kepentingan klien dan untuk membangun serta memelihara hubungan antara organisasi dengan publik yang saling menguntungkan. Perbedaan digital PR adalah digunakannya media sosial dan alat interaktif yang dapat memfasilitasi komunikasi dua arah sehingga memicu terjadinya dialog.

Merencanakan PR online tidak berbeda dengan perencanaan PR tradisional. Peluang online perlu dianalisis secara kritis dan tujuan serta sasaran yang spesifik dan terukur dinyatakan dengan jelas. Selain itu, pesan dan media harus sesuai dengan kebutuhan, minat, ketertarikan, kemampuan, dan kebiasaan mereka di media daring. Meskipun publik sekarang mengharapkan organisasi yang melek akan teknologi. Organisasi juga harus memilih tools dan dan dapat mengevaluasi secara kritis efektivitas dan efisiensi setiap alternatif. Keuntungan adanya PR secara daring sendiri adalah kemudahan dalam melacak aktivitas pengguna dan dapat memberikan insight yang berharga. Berbagai media dapat digunakan sebagai 
bagian dari Digital PR, diantaranya: Situs web, blog, halaman jejaring sosial, wiki, program podcast dan YouTube. Penentuan strategi yang menarik tetap perlu mempertimbangkan integrasi secara offline dan daring. Promosi daring mencakup teknik pengoptimalan mesin telusur (SEO) dan atau iklan teks daring berbayar maupun iklan bergambar (Heath, 2013).

\section{a. Fungsi e-PR}

Berikut ini merupakan beberapa fungsi digital PR menurut Heath, 2013):

1) Messaging. Adanya penyebaran informasi melalui email, teks dan pesan instan, dan layanan mikro-bloging.Pesan ditargetkan pada audiens yang diberikan izin untuk ikut serta atau telah menjadi pengikut suatu instansi. Messaging berfokus pada komunikasi kepada pihak eksternal namun tetap menyediakan mekanisme untuk membalas dan berbagi pesan dengan orang lain.

2) User access, memungkinkan publik untuk memperoleh informasi organisasi. Penggunaan situs web organisasi atau perusahaan dan aplikasi seluler dioptimalkan. Situs web bersponsor menjadi platform dasar bagaimana organisasi mempertahankan keberadaannya di ruang digital dan pengguna dapat diarahkan ketika mereka menerima email, mencari di Google atau Yahoo, hyperlink atau iklan bergambar.

3) e-Publishing, merupakan produksi publikasi elektronik yang sejajar dengan buletin tradisional, majalah, laporan tahunan, dan publikasi cetak bentuk panjang lainnya. Ebuletin maupun bentuk publikasi digital lainnya (ebook, e report, dan sebagainya) biasanya didistribusikan melalui email sebagai media promosi perusahaan.

4) Opinion \& advice sharing, dapat dilakukan melalui email, situs web dan aplikasi, dan publikasi elektronik serta alat online yang dirancang khusus untuk tujuan tertentu. Fungsi ini dapat dilakukan melalui berbagai media terkini.

5) Networking menggiring organisasi ke dalam jaringan orang-orang yang berkumpul secara online di situs jejaring sosial seperti Facebook, maupun Instagram, serta situs publik tempat orang berbagi rekomendasi dan komentar tentang berbagai topik.

6) Collaboration, merupakan fungsi untuk memecahkan masalah dengan mencari berbagi informasi tentang topik tertentu menggunakan forum online, wiki, dan webinar interaktif serta konferensi web. Banyak dari alat kolaborasi publik ini tidak memerlukan keanggotaan dan bahkan memungkinkan orang untuk berpartisipasi secara anonim.

7) Instruction, merupakan fungsi utama e-PR untuk tujuan pelatihan dan pengembangan organisasi dan untuk layanan pelanggan dan dukungan teknis. Alatnya mencakup video pelatihan, screencast, tayangan slide, webcast, maupun webinar. 


\begin{abstract}
User enggagement atau keterlibatan pengguna berusaha untuk memperkuat minat atau loyalitas pengguna yang memiliki ikatan terhadap produk, organisasi atau layanan, dengan memberikan kesempatan untuk berpartisipasi dalam aktivitas hiburan. termasuk menonton video hiburan di situs berbagi media seperti YouTube, keterlibatan dalam situs dunia virtual, maupun partisipasi dalam lomba.
\end{abstract}

\subsection{Stakeholder Theory}

Teori pemangku kepentingan atau stakeholder theory, disampaikan oleh Robert Heath (2013) memberikan pemahaman tentang bagaimana individu, kelompok, dan organisasi eksternal memengaruhi organisasi mereka dan bagaimana organisasi memengaruhi pemangku kepentingannya. Teori tersebut menyatakan bahwa kesuksesan PR tergantung pada bagaimana organisasi mengelola hubungan dengan pemangku kepentingan. Stakeholder, pada dasarnya, adalah audiens untuk pesan, praktik, dan kebijakan organisasi.

Teori ini menyajikan landasan bahwa organisasi harus menjalin hubungan dengan pemangku kepentingan untuk memperoleh sumber daya, nilai yang berharga serta mengurangi ketidakpastian. Salah satu prinsip utama teori pemangku kepentingan adalah bahwa organisasi harus memperhatikan kebutuhan pemangku kepentingan yang lebih luas. Stakeholder theory berupaya untuk mengidentifikasi dan mengelola beragam kebutuhan, nilai, dan kepentingan berbagai pemangku kepentingan dan potensi komunikasi antara kelompok-kelompok ini serta antara organisasi dan mereka.

\section{Metode Penelitian}

Penelitian ini menggunakan metode penelitian kualitatif deskriptif. Penelitian kualitatif bertujuan untuk menjelaskan suatu kejadian dengan fokus kedalaman data yang dikumpulkan (Kriyantono, 2014). Pada penelitian kualitatif bertujuan untuk mendeskripsikan data secara faktual, sistematis dan akurat (Kriyantono, 2014).

Metode penelitian ini adalah studi kasus, yaitu: metode yang memanfaatkan berbagai sumber data yang dapat digunakan untuk meneliti, menjelaskan, serta menguraikan secara luas atas berbagai macam aspek yang diteliti secara sistematis, termasuk individu, kelompok, program, organisasi maupun peristiwa. Penggunaan metode studi kasus dapat memberikan penjelasan yang komprehensif mengenai subjek diteliti (Nurdin \& Dra Sri Hartati, 2019). Teknik pengumpulan data dilakukan dengan observasi teks dan wawancara dengan KP selaku owner Dejavato dan RS selaku Humas serta pengelola media sosial Dejavato.

Metode yang digunakan dalam pengumpulan data adalah dengan menggabungkan tiga pengumpulan data kualitatif yaitu wawancara, observasi, serta dokumentasi. Ketiga metode dipilih guna menjadikan data penelitian yang lengkap serta dapat dianalisis dari berbagai sudut pandang. Penelitian dilakukan mulai Maret hingga Desember 2020. Informasi yang disajikan berhubungan dengan pelaksanaan media baru dan daring. Serta ruang 
yang dipilih untuk melakukan penelitian yaitu media digital resmi Dejavato, seperti Instagram dan Youtube. penelitian dilakukan dengan teknik wawancara dengan ketua umum dan PR Dejavato, observasi, serta pengumpulan dokumen terkait.

\section{Hasil Penelitian dan Pembahasan}

Berdasar hasil temuan penelitian yang dilakukan menunjukan bahwa selama pandemi Covid-19 terjadi, Dejavato melakukan dua upaya utama untuk mempertahankan eksistensinya yang fokus pada pengembangan program berbasis visi misi.

Awalnya sebelum terjadi pandemi, dalam menjalankan misinya Dejavato melakukan berbagai progamnya secara tatap muka atau luring. Namun di masa pandemi, untuk meminimalisir peningkatan penyebaranvirus Covid19 maka diberlakukan kegiatan pemberhentian sementara untuk program voluntery. Untuk terus mempertahankan eksistensi Dejavato, maka diberlakukanlah beberapa program secara daring.

Stakeholder theory, disampaikan oleh Robert Heath (2013), menyatakan bahwa kesuksesan PR tergantung pada bagaimana organisasi mengelola hubungan dengan pemangku kepentingan. Pada prakteknya, Dejavato di masa pandemi berupaya mengoptimalkan penggunaan media digital sebagai sarana menyampaikan misi mereka kepada stakeholder dan mempertahankan eksistensi Dejavato sebagai lembaga volunteering.
Teori stakeholder juga menyatakan bahwa organisasi harus menjalin hubungan dengan pemangku kepentingan untuk memperoleh sumber daya, nilai yang berharga serta mengurangi ketidakpastian.

Strategi yang dilakukan oleh Dejavato selaras dengan konsep Stakeholder theory, yaitu Pemusatan kegiatan dari bentuk kegiatan luring menjadi kegiatan daring, atau konvergensi program dalam menyampaikan misi organisasi. Program ini merupakan kategori fungsi PR dalam kolaborasi dan berbagi. Program daring Dejavato merupakan bentuk dari pertukaran opini antara organisasi dengan publik selaku pemangku kepentingan. Bahkan di dalam konvergensi yang dilakukan, terkadang juga membahas mengenai solusi atas masalah yang ada.

Pelaksanaan program daring yang dilakukan oleh Dejavato dibagi menjadi 3 kategori yaitu Short Term, Mid Term, serta Long Term. Hasil wawancara menunjukan bahwa hanya satu dari tiga kategori di atas yang sejauh ini berhasil dilaksanakan. Hal yang ditekankan menjadi inti dari kegiatan kerelawanan yaitu sisi humanis.Berikut pernyataan KP selaku ketua Dejavato "kemudian mid term atau long term, ada juga pembelajaran bahasa, ya. itu ya kurang menarik juga ternyata"

Program daring yang berhasil dilaksanakan oleh Dejavato yaitu program dengan kategori short term program, yaitu workcamp yang berdurasi 1-2 jam dari pelaksanaan normal yang berkisar 10 hari. Sejauh ini untuk pelaksanaan mid-long term 
program dirasa belum efektif bahkan tidak berhasil berjalan karena ada proses luring yang tidak bisa dengan mudah dipindahkan menjadi daring karena berbagai faktor.

Dari pelaksanaan program daring yang dilakukan, terdapat beberapa dampak positif yang dirasakan oleh Dejavato diantaranya: bertambahnya peserta yang turut berpartisipasi dan alokasi waktu yang lebih fleksibel tanpa terbatas jauhnya lokasi setiap peserta. KP menyatakan bahwa dalam proses pelaksanaan program daring, terdapat esensi utama yang hilang, yaitu kemanusiaan dan pengalaman langsung.

Sesuai dengan fungsi hubungan masyarakat di sebagian besar organisasi nirlaba, melaksanakan program secara daring ini dapat dikategorikan upaya dalam mengembangkan, memelihara, dan memantau fokus masalah organisasi, kebijakan organisasi, dan kebijakan publik yang relevan dengan organisasi; dengan adanya kesadaran keharusan melaksanakan program sebagai bentuk kesadaran kebijakan publik dalam pelaksanaan kegiatan di masa pandemi.

Implementasi program daring juga merupakan bentuk dari tujuan hubungan masyarakat Performance Objective, yaitu tujuan PR untuk merepresentasikan citra dari organisasi kepada pemangku kepentingan atau publiknya. PR dapat mengadakan berbagai program dalam upaya membentuk dan menambah identitas organisasi di pandangan publik (Nova, 2011).

Adanya program-program yang beralih dari luring menuju daring ini merupakan strategi untuk menjaga citra bahwa Dejavato merupakan organisasi yang memiliki identitas sebagai organisasi yang menjembatani masyarakat lokal dengan orang luar negeri, dengan tujuan berbagi dan interaksi sebagai aspek utama volunteering. Pelaksanaan program daring juga memiliki pesan tersendiri bahwa Dejavato bukan organisasi yang tidak siap dengan perkembangan teknologi. Dejavato tetap berusaha agar terhubung dengan para pemangku kepentingannya dengan cara membuat program yang tidak mungkin dihadiri dapat diikuti meskipun secara daring.

\subsection{Menggiring Opini melalui e-PR untuk Menjaga Eksistensi}

Ketersediaan informasi menjadi fokus Dejavato saat pandemi ini sebab menurut Pratiwi, dkk, (2020) Kebutuhan informasi muncul dari keadaan anomali pada pengetahuan. Para pencari informasi mencari apa yang tidak mereka miliki, sehingga adanya kebutuhan akan sesuatu yang dibutuhkan. Pada kasus kali ini, Dejavato bertujuan memberikan pengetahuan tentang eksitensi mereka di pandemi.

Secara umum, strategi atau program yang dilakukan secara daring ini termasuk dalam kategori messanging. Dimana publik dapat melakukan fungsi ini melalui fitur media sosial yang banyak tersedia saat ini yaitu berbagi pesan yang dapat diperoleh dari media sosial, maupun email resmi. Di samping itu penggunaan web, serta media sosial Dejavato merupakan bentuk fungsi user access, di mana publik dapat mencari info resmi dari web maupun Instagram resmi Dejavato. Selain 
menyediakan informasi resmi mengenai Dejavato, penggunaan media sosial ini juga merupakan bentuk fungsi networking sesuai yang diungkapkan Heath (2013).

Aktivitas yang dilakukan selama pandemi merupakan upaya untuk menjaga eksistensi organisasi pada opini stakeholder melalui aktivitas siber, atau aktivitas e-PR. Aktivitas e-PR (Heath, 2013) merupakan kegiatan yang mencakup hubungan masyarakat tradisional seperti komunikasi antarpribadi dengan menggunakan Internet dan teknologi nirkabel seluler untuk mengelola komunikasi, untuk menjembatani kepentingan publik, dan untuk membangun serta memelihara hubungan antara organisasi dengan publik yang saling menguntungkan. PR daring memiliki perbedaan, yaitu dengan penggunaan media sosial dan alat interaktif yang dapat memfasilitasi komunikasi dua arah dapat memicu terjadinya dialog.

Forum publisitas khususnya media sosial Instagram menjadi alat yang aktif digunakan dalam setiap langkah yang dilakukan Dejavato untuk menjalankan visi misi serta dalam menjalakan strategi mempertahankan eksistensi selama pandemi. Pemilihan media Instagram dinilai sebagai media sosial yang paling diminati oleh kalangan muda, yang menjadi target organisasi sendiri. Berdasar hasil penelitian, media selanjutnya yang digunakan oleh Dejavato adalah YouTube, Twitter, dan Facebook. Memaksimalkan penggunaan media sosial menjadi salah satu pilihan mutlak bagi Dejavato karena menjadi satu-satunya cara untuk bisa menjangkau khalayak luas dalam menjalankan program daringnya.

Hal tersebut dikuatkan dengan pendapat Pratiwi, dkk, (2019) bahwa Public Relation membutuhkan media sebagai alat pendukung untuk terciptanya komunikasi atau sebagai media penyampaian pesan yang efektif. Public Relation merupakan sarana penghubung yang digunakan oleh perusahaan kepada publiknya guna mencapai tujuan tertentu baik secara internal maupun eksternal. Oleh sebab itu Dejavato dalam aktivitas PR menggunakan media sosial sebagai kanal PR mereka.

Pemilihan media Instagram sebagai media publikasi pertama yang digunakan oleh Dejavato tentu saja bukan tanpa alasan. Hal ini dikarenakan Instagram merupakan media sosial dengan pengguna terbesar kedua di Indonesia. Jumlah keseluruhan pengguna Instagram di Indonesia hampir 66 juta pengguna. tercatat pada April 2020, 45 juta berusia antara 18 dan 34 tahun, dengan 24 juta berusia antara 18 dan 24 tahun. Indonesia bahkan berada di urutan keempat dalam pengguna Instagram secara internasional (Pupprecht, 2020). Hal tersebut juga didukung oleh hasil penelitian sebelumnya mengenai efektivitas Penggunaan Media Sosial sebagai Media Promosi Wisata oleh Oktaviani \& Fatchiya, (2019). Hasil penelitian menunjukan bahwa penggunaan media sosial sebagai media promosi wisata Umbul Ponggok sangat efektif dalam tahap interest \& desire. Pada tahap action, Instagram berada pada kategori efektif sedangkan laman web berada pada kategori cukup efektif. Dapat disimpulkan bahwa di Indonesia 
merupakan media sosial yang memiliki dampak yang cukup besar dalam hal promosi.

Hal ini selaras dengan yang dilakukan oleh Dejavato yang dirasa sudah cukup tepat dalam memilih Instagram sebagai alat spesifik untuk menyasar kaum muda. Interaksi yang terjadi tetap menjadi poin penting yang ditekankan oleh Dejavato dan interaksi juga merupakan tujuan utama $e-P R$. Oleh sebab itu, adanya komunikasi dua arah seperti tanggapan berupa komentar, like dan share menunjukan bahwa organisasi peduli terhadap pemangku kepentingan serta sisi humanisme perlu digiatkan dalam melaksanakan strategi penggunaan media sosial ini. Selain itu, pesan dan media harus sesuai dengan kebutuhan, minat, ketertarikan, kemampuan, dan kebiasaan publik di media daring. Berikut pernyataan RS selaku koordinator pengelola konten media "Konten di media sosial, sih, kita lebih kalau ada hari-hari besar, kita bikin poster ucapan selamat hari raya juga bikin promosi programprogram online kita, partner kita dan update kegiatan di Dejavato apa saja sama pandemi kemudian karena kita berharap 2021 sudah mulai lagi, ternyata belum. jadi ya kontenkonten eksis aja sekarang".

Dalam upaya mempertahankan komunikasi secara efektif dengan pemangku kepentingan serta memberikan informasi (Heath, 2013), Dejavato melakukan aktivitas melalui media sosial khususnya Instagram sebagai media komunikasi dua arah. Dejavato memberikan informasi mengenai programprogram yang bersifat spontan, serta ucapan pada saat tertentu seperti hari besar agama untuk menjaga jalur komunikasi dengan stakeholder. Pembaharuan konten pada pandemi juga lebih diperhatikan oleh Dejavato karena semenjak program dihentikan tidak ada pembaharuan kegiatan yang signifikan. Tidak dapat dipungkiri bahwa keterlibatan Dejavato dengan publik menurun dibanding sebelum adanya pandemi namun diharapkan upaya yang dilakukan Dejavato mampu menjaga interaksi dengan stakeholder-nya.

Selain memilih tools, organisasi juga harus mengevaluasi secara kritis efektivitas dan efisiensi setiap alternatif yang di ambil. Keuntungan adanya PR daring sendiri adalah kemudahan melacak aktivitas pengguna, serta dapat memberikan insight yang berharga. Satu hal yang perlu diperhatikan adalah, dalam lingkungan komunikasi seperti saat ini yang terbagi-bagi, keberadaan daring suatu organisasi perlu terus dipromosikan (Heath, 2013).

Sesuai dengan pernyataan di atas, Dejavato, dalam melaksanakan kegiatannya di Instagram khususnya, telah berhasil melaksanakan pengumpulan data secara sederhana, serta mempromosikan beberapa konten yang pada akhirnya menjadi konten populer dan membawa mengenalkan Dejavato kepada masyarakat secara lebih luas.

\subsection{Dejavatalk sebagai Strategi Jangka Panjang Menarik Minat Publik}

Konvergensi program Dejavato Discovery menjadi Dejavatalk juga menjadi solusi di masa pandemi yang dilakukan oleh Dejavato. Program ini merupakan bentuk fungsi user 
enggagement serta opinion sharing yang dikemukakan oleh Heath (2013). Dejavatalk merupakan program yang diluncurkan semenjak awal pandemi melalui media YouTube, namun menggunakan Instagram sebagai media promosinya.

RS menjelaskan bahwa program Dejavatalk ini memiliki tujuan jangka panjang yaitu implementasi program secara normal (dilakukan dengan tatap muka setelah pandemi) atau seperti sedia kala. Tujuan jangka pendek yang diharapkan adalah antusiasme penonton dalam mengikuti kegiatan Dejavatalk ini. Berikut pernyataan RS:"efek jangka pendek sudah banyak sih yang tanya-tanya lewat email, banyak yang lewat DM Instagram, banyak lewat WhatsApp Dejavato".

Penggunaan visual atau ilustrasi merupakan hal yang efektif, dalam hal ini penggunaan media video sebagai penghantar pesan di strategi Dejavatalk dinilai lebih efektif. Hal ini didukung pendapat Maemona, dkk, (2020) bahwa penggunaan ilustrasi dalam komunikasi persuasif akan lebih mudah sampai kepada target persuasif. Visual merupakan hal yang relatif mudah diterima dan dicerna oleh target atau audience.

Dejavatalk dapat dikategorikan dalam upaya menciptakan kesadaran dan penerimaan misi organisasi (Heath, 2013) yaitu: dengan adanya pengaruh terhadap publik dengan cara memberikan informasi mengenai kegiatan volunteering melalui Dejavato. Dejavatalk mendapat umpan balik yang cukup baik dengan adanya beberapa komentar yang mendukung konsep video-video tersebut, memicu adanya pengalaman yang dibagikan melalui komentar oleh publik lain, maupun dukungan bagi para sukarelawan yang menjadi narasumber tersebut. Tujuan awal untuk mempertahankan eksistensi dapat disebut sebagai strategi yang sukses dengan adanya interaksi serta intensi yang ditunjukkan oleh para publik selaku stakeholder eksternal.

Dejavatalk merupakan hasil kegiatan e-PR dalam pemanfaatan forum publisitas yang diungkapkan oleh Onggo (2004), di mana dalam forum ini praktisi dapat mengidentifikasi tren baru, pesaing, serta riset pasar sebagai insight bagi pemasar. Media yang umum digunakan adalah seperti media sosial dan blog. Youtube menurut Nasrullah, (2015) termasuk kategori sharing media, yaitu media yang membolehkan pengguna untuk berbagi macam-macam dokumen baik video, gambar, audio, dan dokumen umum lainnya.

Dejavatalk merupakan kegiatan pemanfaatan media berbagi dengan komunikasi dua arah. Program ini termasuk ke dalam tujuan humas Performance Objective, yaitu tujuan PR untuk merepresentasikan citra dari organisasi kepada pemangku kepentingan atau publiknya.

PR dapat mengadakan berbagai program dalam upaya membentuk dan menambah identitas organisasi di pandangan publik (Nova, 2011). Dejavato melalui program Dejavatalk ini berupaya merawat citra sebagai penyalur volunteer, organisasi yang aktif dalam mengenalkan volunteering sesuai misi mereka, serta menambahkan 
citra sebagai organisasi yang aktif meskipun terhalang pandemi. Dejavatalk juga mencakup tujuan humas kedua yaitu Support of Consumer market objective karena Dejavato menciptakan kegiatan yang dapat difungsikan sebagai pengidentifikasi masalah melalui pengumpulan tanggapan publik. Spesifiknya melalui kolom komentar yang diberikan penonton. Di samping pencapaian tersebut, Onggo (2004) menyebutkan bahwa salah satu tujuan e-PR adalah komunikasi dua arah, yang diharapkan akan membentuk hubungan yang kuat dan bermanfaat yang tidak didapat seperti pelaksanaan dengan media luring.

Melalui Dejavatalk, Dejavato dinilai masih perlu memperhatikan bentuk komunikasi dua arah dengan cara menanggapi komentar terkait yang berada di fitur komentar YouTube, berdasarkan observasi, Dejavato masih mengabaikan beberapa dari tanggapan publik tersebut.

\subsection{Strategi $\quad$ Terpadu Pemberdayaan Publik di Masa Pandemi}

KP selaku Founder Dejavato menyatakan terkait Program pemberdayaan dalam rangka menjalankan misi di masa pandemi, yaitu membentuk The Dije serta Tim Satgas Covid-19. Kegiatan tersebut termasuk dalam kategori fungsi e-PR dalam collaboration di mana dalam program terpadu ini merupakan upaya dalam menyelesaikan atau membantu masalah dalam pandemi ini. Fungsi e-PR lainnya adalah instruction di mana Dejavato berupaya menjadikan masyarakat berdaya dengan adanya pelatihan atau instruksi khusus di kedua program.

The Dije merupakan usaha makanan tradisional yang dibentuk dengan tujuan pemberdayaan Ibu rumah tangga di lingkungan sekitar yang nantinya dipromosikan serta dipasarkan secara daring.

Sesuai dengan misi ke empat organisasi, yaitu Meningkatkan kepedulian dan tanggung jawab terhadap lingkungan sosial. Dejavato memberikan timbal balik kepada masyarakat selama pandemi ini dengan cara mengadakan pemberdayaan warga sekitar yang kemudian dilakukan promosi dan pemasaran secara daring, serta mengedukasi masyarakat sekitar dalam upaya menangani Covid melalui media sosial melalui The Dije serta pembentukan Tim Satgas Covid-19.

Salah satu prinsip utama teori pemangku kepentingan menurut Robert Heath (2013) adalah bahwa organisasi harus memperhatikan kebutuhan pemangku kepentingan yang lebih luas. Dari perspektif hubungan masyarakat, teori pemangku kepentingan berupaya untuk mengidentifikasi dan mengelola beragam kebutuhan, nilai, dan kepentingan berbagai pemangku kepentingan dan potensi komunikasi antara kelompok-kelompok ini serta antara organisasi dan mereka. Untuk pemenuhan kebutuhan pemangku kepentingan yang lebih luas, Dejavato membentuk The Dije dengan tujuan memberdayakan ibu rumah tangga sekitar yang mana selama ini fokus organisasi banyak dikerahkan pada penyampaian misi volunteering. Adanya pandemi menjadikan Dejavato memiliki 
waktu lebih dalam kegiatan pemberdayaan yang bersifat lokal. Selain itu, Tim Satgas Covid-19 RW 08 yang berpusat di kantor Dejavato merupakan program yang disebar melalui media daring seperti Instagram dan WhatsApp terutama untuk warga RW 08 Bukit Panjangan Asri.

Hal tersebut merupakan hasil identifikasi dan pengelolaan beragam kebutuhan, nilai, dan kepentingan berbagai pemangku kepentingan yang lebih luas. Kedua kegiatan pemberdayaan tersebut dapat dikategorikan dalam tujuan humas Performance Objective, yaitu tujuan PR untuk merepresentasikan citra dari organisasi kepada pemangku kepentingan atau publiknya. PR dapat mengadakan berbagai program dalam upaya membentuk dan menambah identitas organisasi di pandangan publik. Dejavato melalui program pemberdayaan ini, berupaya untuk membentuk identitas organisasi sebagai organisasi sosial, di samping identitas sebagai organisasi volunteering luar negeri.

\section{Simpulan}

Dejavato Foundation merupakan organisasi swadaya masyarakat yang mengalami dampak dari Pandemi saat ini. Mereka memiliki fokus masalah utama yaitu terdampaknya pelaksanaan misi yang telah ditentukan. Ditemukan bahwa dalam pengambilan keputusan, organisasi tidak dapat berjalan sepihak namun harus berjalan sinkron dengan para pemangku kepentingan, yang artinya semua komponen mempengaruhi satu sama lain Umpan balik, pengertian serta perhatian para pemangku kepentingan membuat Dejavato tetap optimis dalam mencari alternatif untuk hasil yang nyata dalam mempertahankan eksistensi di masa pandemi.

Dejavato secara spesifik menggunakan strategi e-PR terlebih pemanfaatan media sosial sebagai media membangun serta menjaga interaksi dua arah antara perusahaan dan para pemangku kepentingan, memusatkan program-program yang memungkinkan dilaksanakan secara daring, memfokuskan promosi jangka panjang, serta media informatif dejavatalk, hingga memberdayakan masyarakat sekitar

\section{Daftar Pustaka}

Asosiasi Penyelenggara Jasa Internet Indonesia. (2020). Infografis Survey Penetrasi dan Perilaku Pengguna Internet Indonesia. Jakarta: APJII

Foundation, D. (2019). About Us. Retrieved October 7, 2020, from

http://dejavato.or.id/assets/uploa d/files/Brosur_Dejavato_2019.p df

Heath, R. L. (2013). Encyclopedia of Public Relations 2nd Edition (Vol. 4). California: Sage Publications.

Kriyantono, R. (2014). Riset Komunikasi. Jakarta: Kencana.

Maemona, R., \& Pratiwi, M. R. (2020). Teknik Asosiasi : Strategi Pesan Dakwah Di Instragram. Jurnal Riset Komunikasi, 3(2), 254-268. https://doi.org/10.38194/jurkom .v3i2.169

Nasrullah, R. (2015). Media Sosial: Perspektif Komunikasi, Budaya, dan Sosioteknologi. Bandung: 
Simbiosa Rekatama Media.

Nova, F. (2011). Crisis Public Relatons Bagaimana PR Menangani Krisis Perusahaan. Jakarta: Raja Grafindo Persada.

Nurdin, I., \& Dra Sri Hartati, Ms. (2019). Metodologi Penelitian Sosial. Surabaya: Media Sahabat Cendekia.

Oktaviani, W. F., \& Fatchiya, A. (2019). Efektivitas Penggunaan Media Sosial sebagai Media Promosi Wisata Umbul Ponggok, Kabupaten Klaten. Jurnal Komunikasi Pembangunan, 17(1), 13-27. https://doi.org/10.46937/172019 26586

Onggo, B. J. (2004). Cyber Public Relations. Jakarta: Elex Media Komputindo.

Pranita, E. (2020). Diumumkan Awal Maret, Ahli: Virus Corona Masuk Indonesia dari Januari. Retrieved October 21, 2020, from

https://www.kompas.com/sains/ $\mathrm{read} / 2020 / 05 / 11 / 130600623 / \mathrm{diu}$ mumkan-awal-maret-ahli-virus-corona-masuk-indonesiadari-januari

Pratiwi, M R, Yusriana, A., \& ... (2019). Identitas Virtual dalam Institusi Pendidikan Melalui Akun @udinus_smg. .... On Communication and .... Retrieved from https://proceeding.umn.ac.id/ind ex.php/COMNEWS/article/vie $\mathrm{w} / 1100$

Pratiwi, Mutia Rahmi, Hapsari, S. A., \& Yusriana, A. (2019). Refleksi Citra Universitas Dian Nuswantoro Melalui Unggahan di Akun@udinus_smg.Jurnal Penelitian Pers Dan
Komunikasi Pembangunan, 23(2), 79-93. https://doi.org/10.46426/jp2kp.v $23 \mathrm{i} 2.104$

Pratiwi, Mutia Rahmi, Indrayani, H., \& Amalia, S. (2020). Optimasi Pola Pengasuhan Digital dalam Pemenuhan Kebutuhan Informasi. Expose: Jurnal Ilmu Komunikasi, 3(1), 76. https://doi.org/10.33021/exp.v3i $\underline{1.1012}$

Pupprecht, D. A. (2020, September 21). The Rise Of Social Media In Indonesia | Incify - Digital Direct Response Agency. Retrieved January 31, 2021, from https://www.incify.co/therise-of-social-media-inindonesia/ 